\title{
Simulation of nitrate transport and wastewater seepage in groundwater flow system
}

\author{
R. Lalehzari $\cdot$ S. H. Tabatabaei $\cdot$ M. Kholghi
}

Received: 22 April 2012/Revised: 24 January 2013/Accepted: 20 February 2013/Published online: 16 March 2013

(C) Islamic Azad University (IAU) 2013

\begin{abstract}
Groundwater quantity and quality modeling is one approach for optimal use of available water resources in arid and semiarid regions. This study was conducted to simulate flow treatment and nitrate transport on Shahrekord aquifer using three-dimensional solute transport model and geographical information system. Hydraulic conductivity, specific yield and recharge values in flow simulation process and effect molecular diffusion coefficient, longitudinal dispersivity and distribution coefficient in quality model were calibrated. 120 water samples during July 2007 to June 2008 were collected monthly from 10 wells and measurements of nitrate were carried out. The results show that the developed model is successfully used to simulate flow path and nitrate transport in saturated porous media. The highest values of nitrate occur along Bahram-Abad village and the surroundings. The groundwater quality in the area represents a complex system, which is affected by different factors of pollution, such as urban wastewater and leaching of agricultural lands.
\end{abstract}

R. Lalehzari $(\bowtie) \cdot S$. H. Tabatabaei

Department of Water Engineering, Faculty of Agriculture,

Shahrekord University, Shahrekord, Iran

e-mail: lalehzari@hotmail.com

R. Lalehzari

Department of Irrigation and Drainage, Faculty of Water Science

Engineering, Shahid Chamran University, Ahvaz, Khuzestan

Province, Iran

M. Kholghi

Department of Irrigation and Reclamation, Faculty of

Agriculture, University of Tehran, Karaj, Iran
Keywords Aquifer · Modeling - Advection - Dispersion and contamination

\section{Introduction}

Groundwater contamination is a serious problem facing the countries. Because groundwater is vulnerable to contamination from a variety of sources, and, once contaminated, it is very difficult to restore to its original quality (Papadopoulou et al. 2007). In the wake of recent industrialization and fast urbanization, the quality of groundwater has become an increasing concern due to contamination by various toxic substances (Tariq et al. 2007). Potential sources of contamination include recycled irrigation water, wastewater from human activities and waste by-products from industrial activities. Contaminant transport modeling is an essential component of any risk assessment and risk management pertinent to groundwater quality (Wang and Zheng 2005).

Nitrate is an important constituent in fertilizers and is present in relatively high concentrations in human and animal wastes (Tabatabaei and Lalehzari 2009). Human health can be affected when water containing high nitrate concentrations is ingested. Consumption of this water can cause diseases, such as methemoglobinemia in children younger than 6 months and development of cancer in older children and adults (World Health Organization 2006; Pacheco and Cabrera 1997). Nitrate distribution in the groundwater has been widely studied by different tools, such as geographic information systems (GIS) and numerical modeling (Ducci 1999; Obeidat et al. 2007; Andersen et al. 2007; Fetouani et al. 2008; Wang et al. 2008; Ishida et al. 2011).

Nowadays, the numerical modeling technology has become an important method on the groundwater research. 
Many visual numerical modeling software of groundwater based on the different methods have been developed and used widely, such as Finite Element subsurface FLOW system (FEFLOW) (Diersch 2005), Groundwater Modeling System (GMS) (Anon 2000), Visual Modular three Dimensional Flow (Visual Modflow) (Anon 2000), a 2D

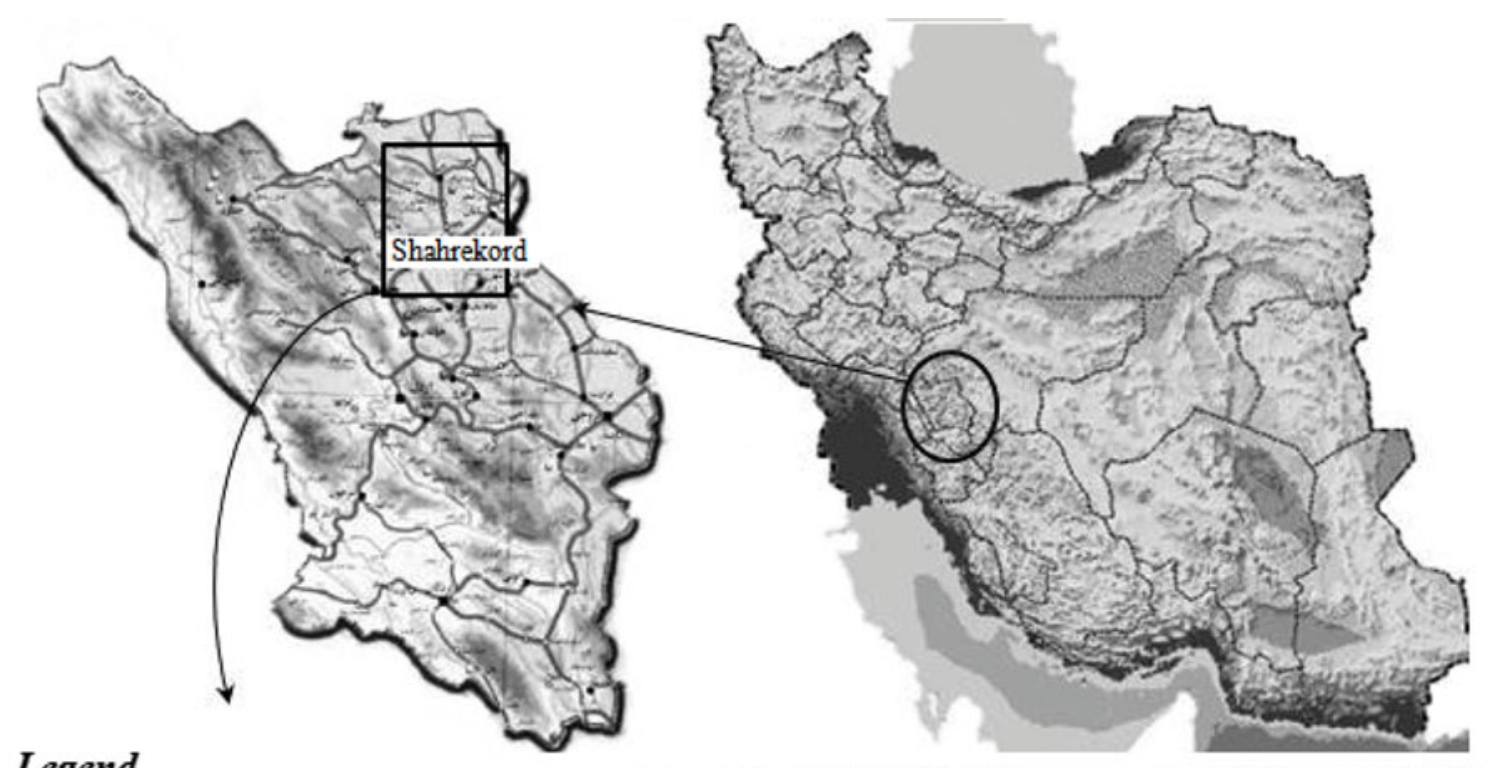

Legend

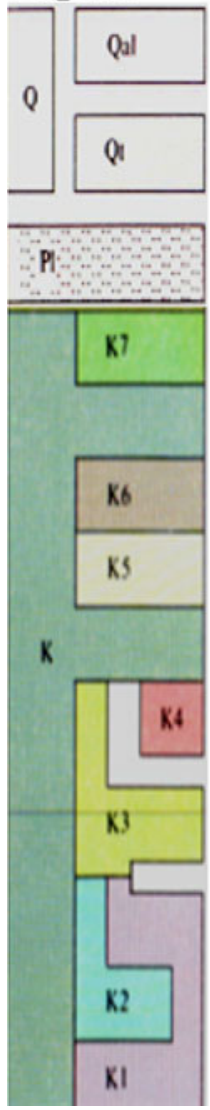

Recent terraces and recent alluviums

Old terraces deposits

Hard conglomerate. Sandstone and gritstone

Marly fossiliferous \& thin sandy argillaceous limestone

Brown dolomite and dolomitized limestone

Shale and marls

Mainly orbitolina limestone and locally evaporitic Reddish Conglomerate and sandstone

Thin gray argillaceous limestone

Reef limestone with corals

Reddish sandstone and shale

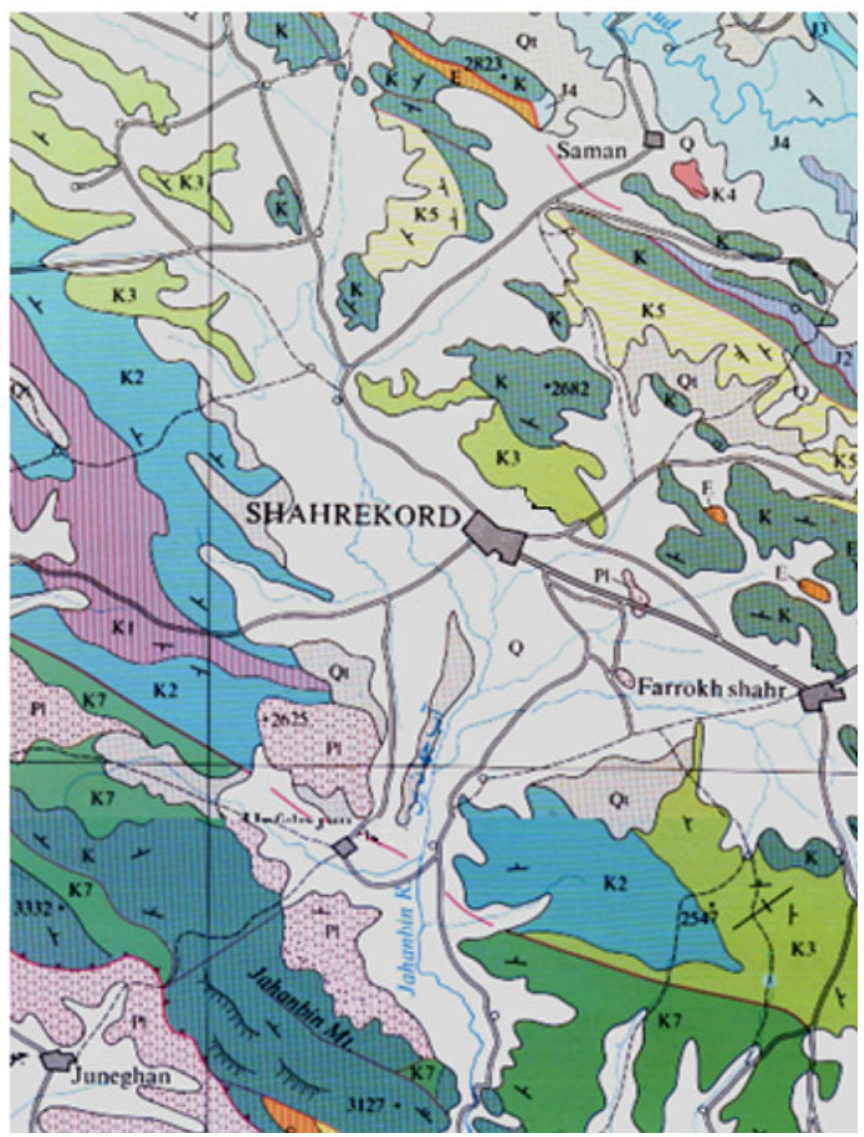

Fig. 1 The situation and geology map of Shahrekord plain 
and 3D geostatistics, uncertainty analysis and visualization software package (UNCERT) (Wingle et al. 1999) and Processing Modflow for Window (PMWIN) (Chiang and Kinzelbach 2000).

PMWIN is a three-dimensional finite-difference groundwater model to the description and prediction of the behavior of flow (Modflow) and solute transport (MT3D). The MT3D transport model uses a mixed EulerianLagrangian approach to the solution of the advective-dispersive-reactive transport equation (Chiang and Kinzelbach 2000). A number of studies have been carried out applied PMWIN model at the groundwater modeling (Gurunadha
Rao and Gupta 2000; Peeters et al. 2004; Lautz and Siegel 2006; Wriedt and Rode 2006).

Modflow is a fully distributed model that calculates round water flow from aquifer characteristics. It solves the three-dimensional groundwater flow equation using finitedifference approximations. The finite-difference procedure requires that the aquifer be divided into cells, where the aquifer properties are assumed to be uniform. The unknown head in each cell is calculated at a point or node at the center of the cell (Conan et al. 2003). The following basic equation is solved by Modflow (Bazargan-Lari et al. 2009):

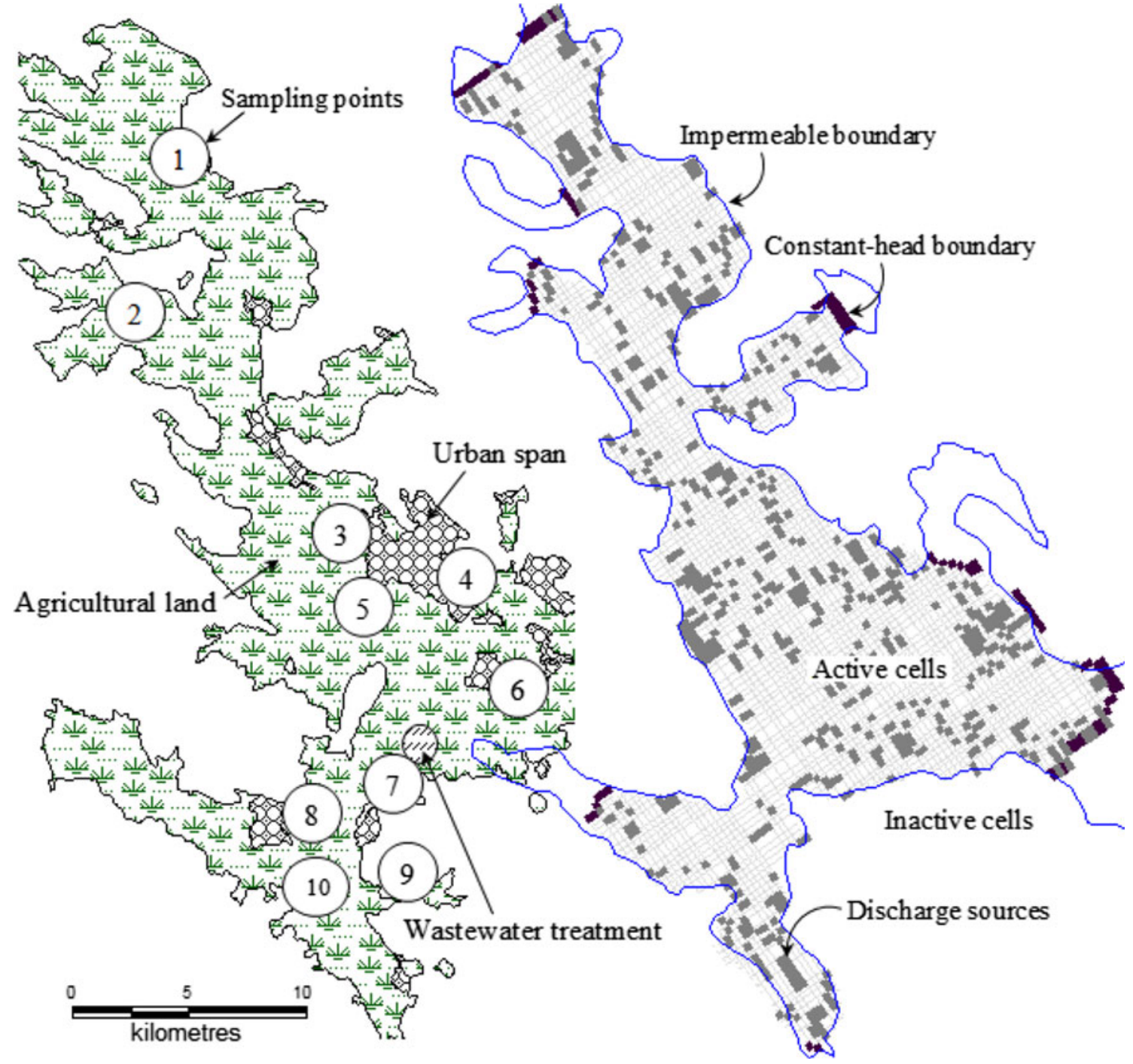

Fig. 2 Water sampling points, land-use and gridding of Shahrekord plain 


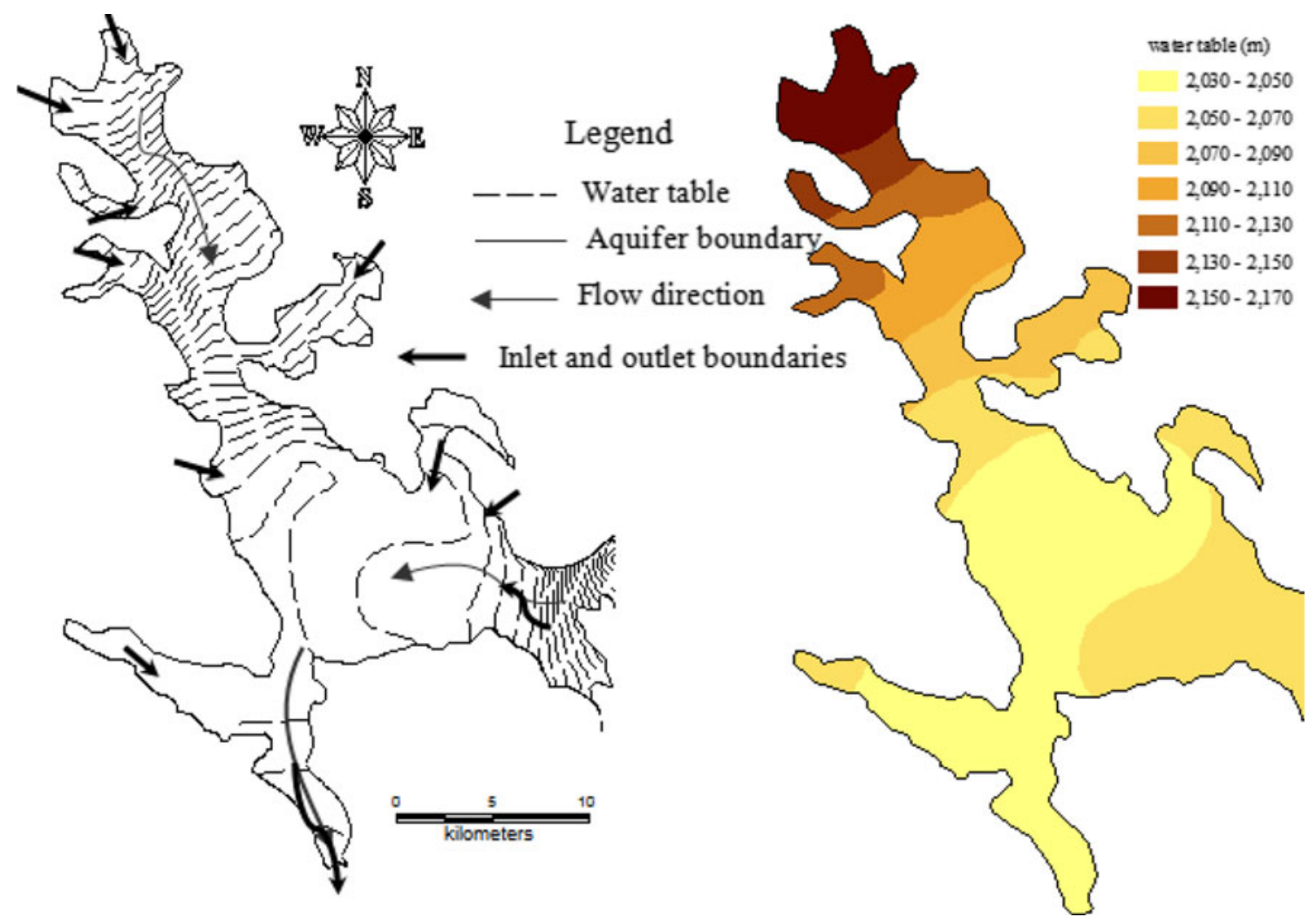

Fig. 3 Hydraulic boundaries and groundwater level

$\frac{\partial}{\partial x}\left(K_{x x} \frac{\partial h}{\partial x}\right)+\frac{\partial}{\partial y}\left(K_{y y} \frac{\partial h}{\partial y}\right)+\frac{\partial}{\partial z}\left(K_{z z} \frac{\partial h}{\partial z}\right)-w=S_{s} \frac{\partial h}{\partial t}$

where $K_{x x}, K_{y y}$ and $K_{z z}$ are the hydraulic conductivities along the $X, Y$, and $Z$ directions, respectively, volumetric flux, $w$, represents a source or sink of water, $h$ is the head of groundwater, $S_{s}$ is the specific storage of the aquifer material, and $\mathrm{t}$ is time.

Solute transport in groundwater is simulated using numerical models based on the partial differential equation describing solute transport in an aquifer. MT3D is a threedimensional solute transport model for simulation of advection, dispersion, and chemical reactions of dissolved constituents in groundwater systems that can be described by the partial differential equation (Zheng 1990):

$\frac{\partial C}{\partial t}=\frac{\partial}{\partial x_{i}}\left[D_{i j} \frac{\partial C}{\partial x_{j}}\right]-\frac{\partial}{\partial x_{i}}\left(C V_{i}\right)+\frac{q_{s}}{\theta} C_{s}+\sum_{k=1}^{N} R_{k}$

where $C$ is contaminant concentration of groundwater $\left(M L^{-3}\right) ; t$ is time $(T) ; x$ is Cartesian coordinates $(L) ; D_{i j}$ is hydrodynamic dispersion coefficient; $\theta$ is porosity; $C_{s}$ solute concentration $\left(M L^{-3}\right) ; V$ is average flow velocity in porous media and $\sum_{k=1}^{N} R_{k}$ is relative to chemical reactions process.

Faidi et al. (2002) developed a model to simulate chloride transport in a dynamic stream-aquifer system by integrating four existing sub-models using Modflow and MT3D.

Saeed and Bruen (2004) calibrated Modflow and MT3D by field data in the Indus basin of Pakistan. The results showed that increase in horizontal hydraulic conductivity, effective porosity, specific yield, freshwater recharge, transverse dispersivity and number of boreholes in multiborehole skimming wells decreased the salinity of the pumped water.

Don et al. (2005) combined Modflow model with the IBS-1 package (Leake and Prudic 1991) and MT3D to transient flow and solute transport simulation in Shiroishi plain on Kyushu Island, Japan.

Ehteshami and Sharifi (2007) investigated nitrate distribution by MT3D in groundwater resources of Shahr-eRey, Iran. 


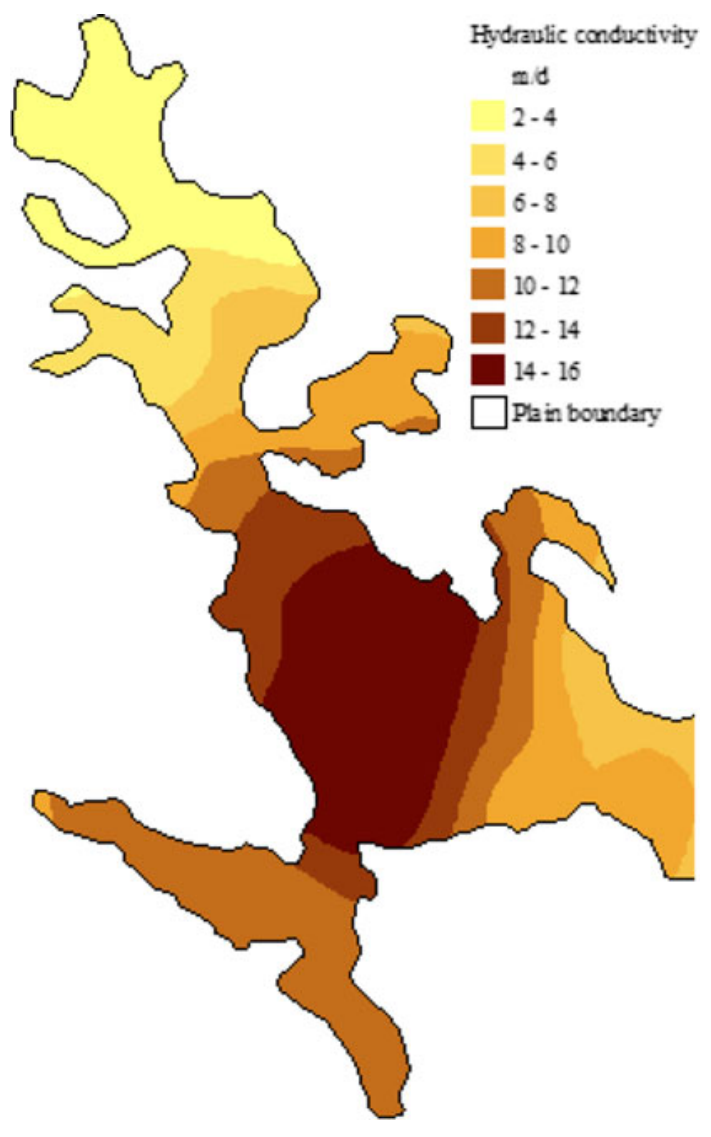

Fig. 4 Hydraulic conductivity map

The objectives of the study were to (1) collect and evaluate hydrogeological data, (2) develop a conceptual model of the groundwater system, (3) construct groundwater flow and nitrate transport models by Modflow (McDonald and Harbaugh 1988) and MT3D (Zheng 1990), respectively. Field studies and simulation were carried out during July 2007-June 2008 in Shahrekord plain.

\section{Materials and methods}

Site area

Shahrekord plain with $551 \mathrm{~km}^{2}$ area is located between $32^{\circ} 07^{\prime \prime}-32^{\circ} 35^{\prime \prime}$ latitude and $50^{\circ} 38^{\prime \prime}-51^{\circ} 10^{\prime \prime}$ longitude at Chaharmahal and Bakhtiari Province, the center of Iran (Fig. 1), and consists of 635 wells, 79 qanats and 40 springs. The discharge volume of depletion sources is about $250 \mathrm{MCM}$ annually. The elevation ranges from 2,030 to $2,300 \mathrm{~m}$, with an average of $2,100 \mathrm{~m}$ above

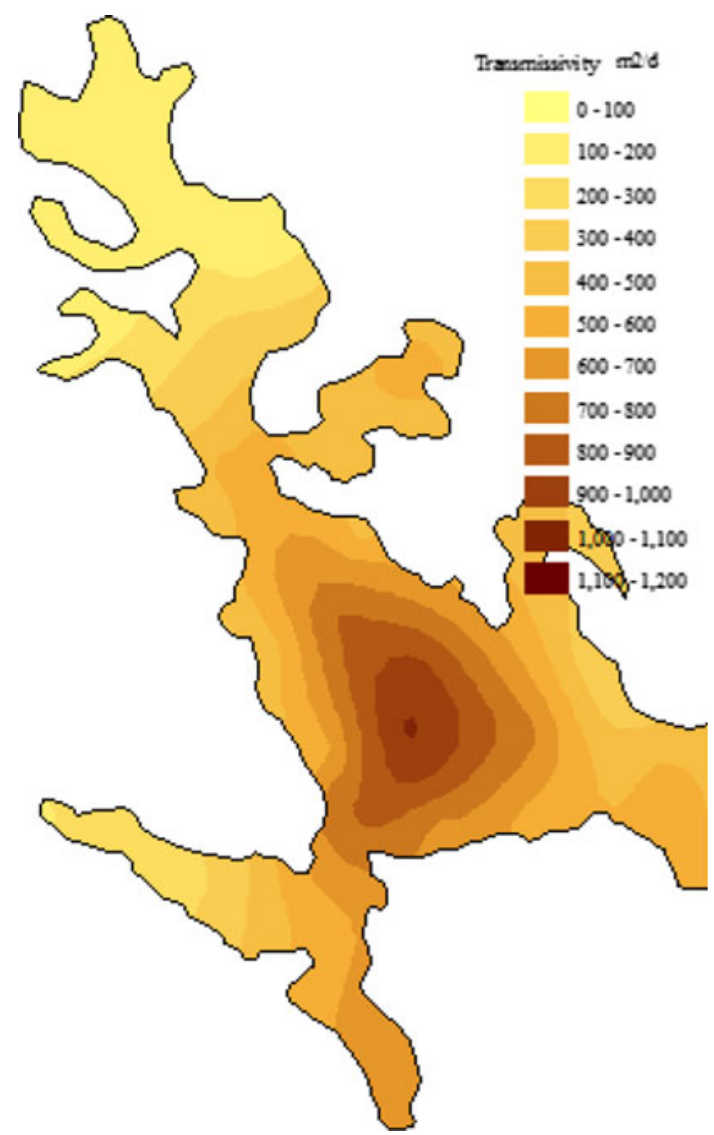

Fig. 5 Transmissivity mapping

sea level, while the mean slope is $0.5 \%$ (Lalehzari 2008).

The average annual precipitation for this site is $120 \mathrm{~mm} /$ year. Based on the previous studies, it was assumed that $28 \%$ of all precipitation over the plain is converted to infiltration (Lalehzari 2008). Shahrekord geology map and are shown in Fig. 1.

Modeling

The simulation is normally composed of two main components: the simulation of water movement and the simulation of solute transport. Each of the two components incorporates several processes.

The first step in solution of groundwater partial difference equations by Modflow is plain discretization. Hydraulic and hydrogeological properties in a cell of grid are constant. A block-centered finite-difference grid consists of 135 rows, 77 columns and one layer. Cells of size 
Fig. 6 Scatter diagram of calibration (a) and verification (b) (a)

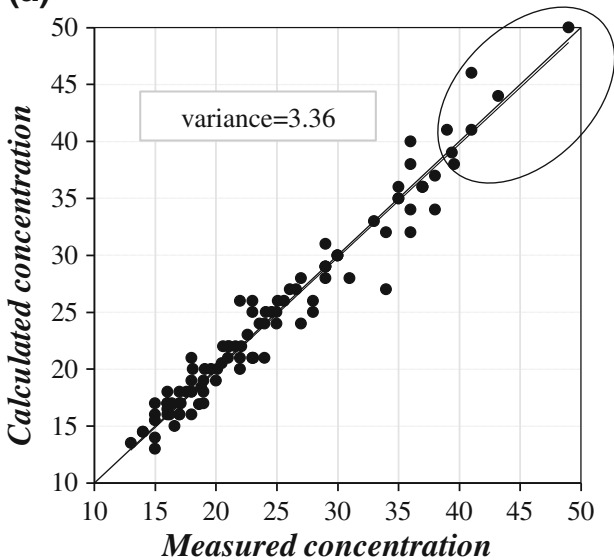

(b)

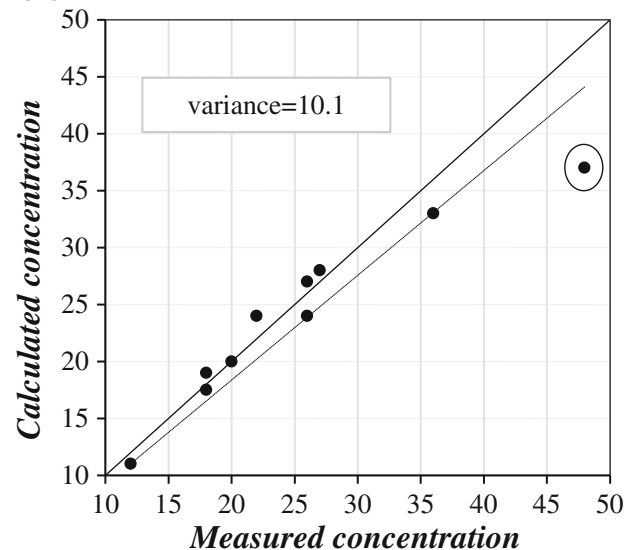

Fig. 7 Simulated and observed nitrate values in Bahram-Abad

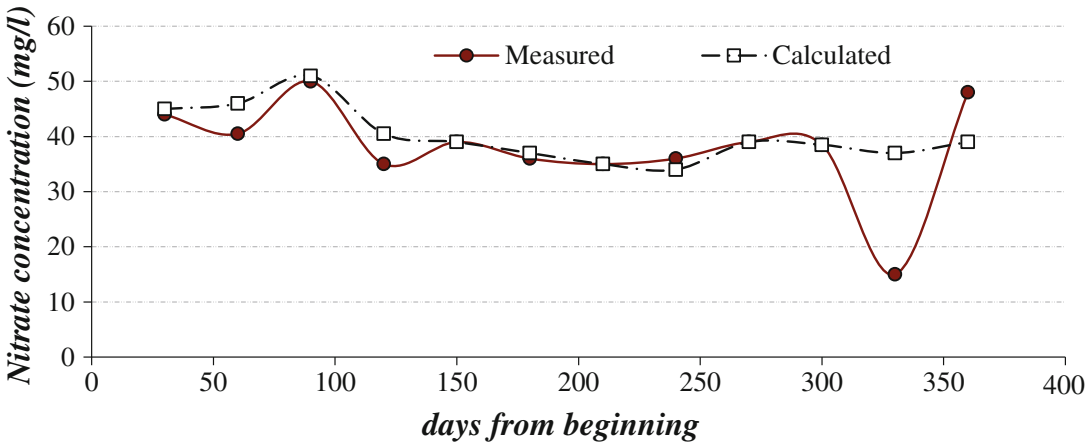

were variable from 250 by $250 \mathrm{~m}$ at near the sampling points and piezometers to 1,000 by $1,000 \mathrm{~m}$.

The simulation period was from 1 July 2007 to 31 June 2008 that divided to 12 stress periods with daily time steps. The basic input data to the flow model are height of water table and discharge by wells of each stress periods and the aquifer parameters, including topography, geometry and soil properties. Inlet parameters are steady on every stress period.

In the nitrate transport model, 120 samples during the period were collected monthly from 10 wells (Fig. 2). Samples were refrigerated at $4{ }^{\circ} \mathrm{C}$ and the measurement of $\mathrm{NO}_{3}$ was carried out within $24 \mathrm{~h}$ of sampling. Land use and well sampling situation in the Shahrekord plain are shown in Fig. 2.

Boundary conditions are a combination of impermeable and constant-head cells represents hills and valleys, respectively (Fig. 2).

The general head boundary is implemented to in or outflow of adjacent aquifers as hydraulic boundaries. Physical or no-flow boundaries are represented by impermeable cells, because they coincide with flow paths. 10 inlet boundaries, an outlet boundary (Tang-Kharaji) and isopiestic lines of groundwater level are shown in Fig. 3. The main direction of groundwater flow is NE-SW following the slope of land surface (Fig. 3).

\section{Results and discussion}

Flow modeling

The flow model for the above conditions is calibrated using groundwater levels from 31 piezometers. The calibration resulted in a good fit to the actual water table elevation data.

Values of hydraulic conductivities, specific yield and recharge were taken from available data, and had been adjusted during a calibration process. As shown in Fig. 4, the ranges of hydraulic conductivities are $2-16 \mathrm{~m} /$ day that southern part and outlet area of plain are the maximum values. Calibrated values of specific yield varied between 0.03 in north to 0.082 in central and south of plain.

Transmissivity mapping (aquifer thickness $\times$ hydraulic conductivity) is interpolated by ArcGIS 9.3 (Fig. 5). 


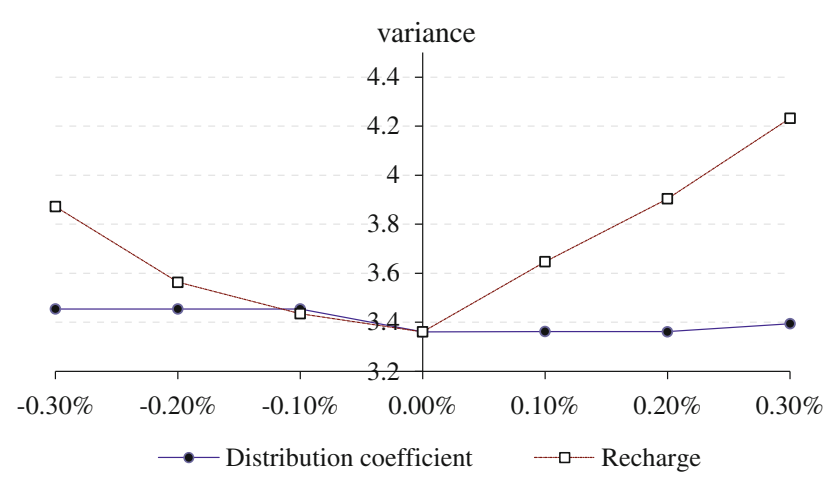

Fig. 8 Sensitivity analysis for nitrate transport

According to the figure, the transmissivity of plain center is greater than $1,000 \mathrm{~m}^{2} /$ day.

Water table mapping (Fig. 3) shows that flow in the northern parts of aquifer is slow and is affected by surface topography, the thickness of saturated layer and variations in hydraulic conductivity (Fig. 4).

\section{Solute transport model}

MT3D model was based on the grid and results of Modflow and sampled NO3 concentrations were input for each stress period (month). The boundary conditions for the transport simulation are dependent on the flow boundary conditions.

In this study, nitrate concentration is used as a proxy for contamination. Effective molecular diffusion coefficient and longitudinal dispersivity were calibrated, while the discrepancies between the pertinent model-generated numbers and the corresponding measurements are reduced to a minimum. The best values for these parameters were calibrated 0 and 5, respectively. Distribution coefficient of 0.0001 is used to linear sorption isotherm in chemical reaction term. Recharge includes rainfall and deep percolation of irrigation water. Nitrate concentrations of different recharge resources were calibrated by their indeterminable.

Effective porosity applied to calculate the actual velocity for advection term. The calibrated effective porosity was varied from 0.21 to 0.33 .

A model simulation was considered to be adequate if it was consistent with the observed data, which were monthly changes in groundwater nitrate concentration. To quantify this consistency, a linear regression of observed data $y$ on model-simulated values $x$ was fitted:

$y=a x+b+\varepsilon$

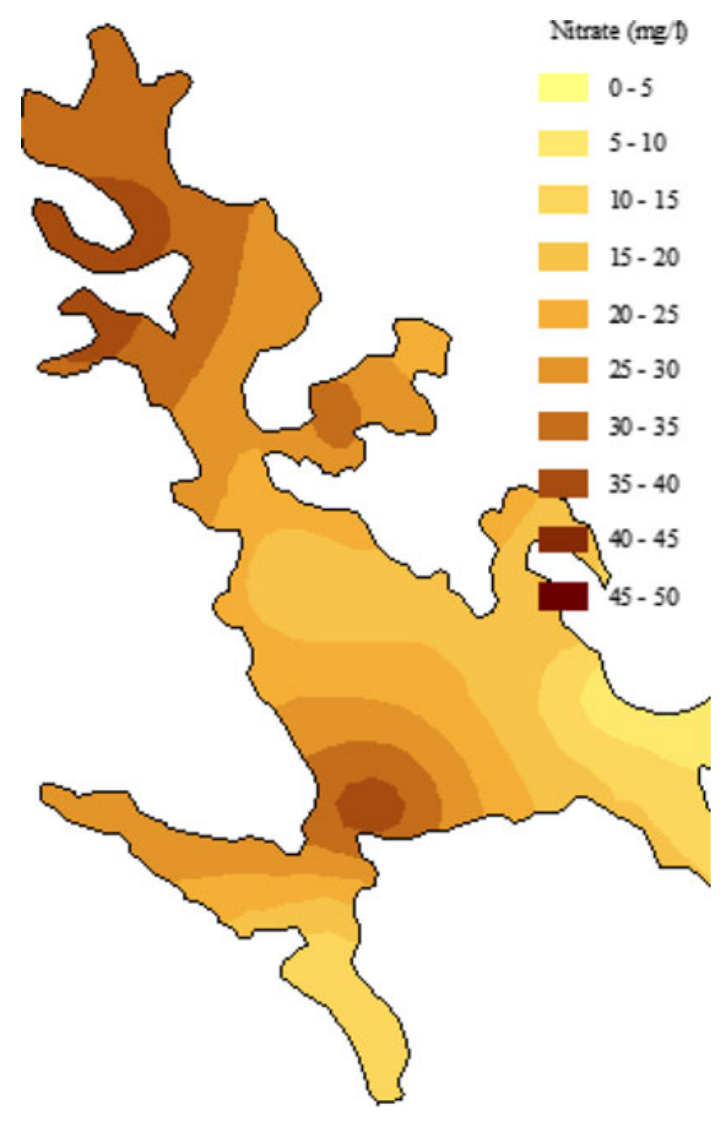

Fig. 9 Observed nitrate in July 2007

and tested whether the data supported the null hypotheses of unit slope $\left(H_{o}: a=1\right)$ and zero intercept $\left(H_{o}: b=0\right)$. If residuals $\varepsilon$ are normally distributed, mutually independent and have constant variance, a $t$ test can be used to test these null hypotheses (Selle et al. 2011).

Figure 6a shows the linear regression of calibration results, in terms of scatterplots by comparing the observed nitrate concentration in the wells to the calculated values in the grid cells.

To test the reliability of the simulations in predicting the spatial and temporal variations of nitrate concentrations in the region studied, a verification was made between the simulated concentrations and the measured concentrations in two last months (May and June 2008). Solid line is 1:1 line and dotted line is fitted regression line. The verification results show that the developed model is successfully used to simulate nitrate transport in the future (Fig. 6b).

Water quality for drinking

During recent years, much legislation has been produced stating the importance of groundwater as a source for 


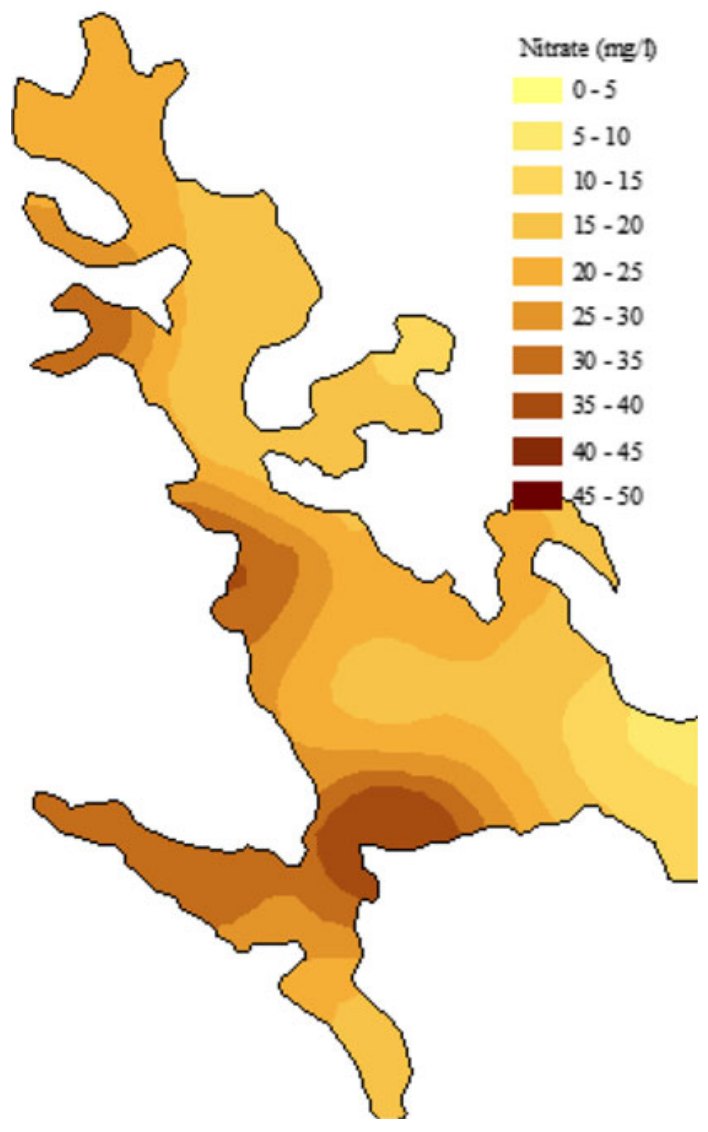

Fig. 10 Predicted nitrate in July 2008

drinking water supplies, underlining its vulnerability and defining the required quality standards (Passarella and Caputo 2006). Water with high nitrate concentration is unfit for human consumption, especially when its concentration exceeded the threshold limit $(50 \mathrm{mg} / \mathrm{L})$ recommended by the health authorities, such as the World Health Organization (WHO) (Obeidat et al. 2007).

Well no.7 located in Bahram-Abad village is used to supply drinking water. Maximum nitrate concentration was measured at this well in all stress periods. The simulated nitrate was higher than standard limit $(50 \mathrm{mg} / \mathrm{L})$ in September 2007 and June 2008.

Conformation of observed and calculated values of the well in 12 stress periods and it difference to other wells in verification stage are shown by a circular line in Fig. 6a, b. As shown in figures, the developed model does not have ability to nitrate simulation in the area.

Chemical parameters and other contaminant, such as calcium, sulfate, ammonium, chloride, sodium, nitrite, total dissolved solids (TDS) and total hardness (TH) in the zone have been studied by Tabatabaei and Lalehzari (2009) and Tabatabaei et al. (2010).
The main concern for the quality of drinking water in the area is the highly variable nitrate concentration because of:

1. Bahram-Abad village do not have wastewater treatment systems and well no.7 located closest to rural wastewater wells.

2. Recessive water of Shahrekord wastewater treatment system (located in north of Bahram-Abad village) returns to the underground flow. The nitrate concentration of it was measured $40 \mathrm{mg} / \mathrm{L}$.

3. The groundwater is affected by groundwater exploitation for agricultural activities.

Calculated and measured nitrate concentrations in the area have been considered as a comparison factor and are shown for all stress periods in Fig. 7.

Sensitivity analysis

A sensitivity analysis was done to investigate the effects of the sensitivity of the model to changes in model input parameters. This procedure was made by changing only one input parameter at a time while keeping all others fixed. The response of the model could be found after each run by observing the change in the shape of the graph (Don et al. 2005).

Variation of distribution coefficient and recharge values was made to assess the importance of each parameter in controlling migration of nitrate in porous media. Figure 8 shows the recharge values have the greatest effect on a model, and the model is slightly more sensitive to increasing recharge amount than it is to decreasing it.

\section{Prediction}

The calibrated parameters and stresses were used to predict the future response of the model for future events. Mapping of predicted nitrate concentrations (July 2008) are shown in Fig. 10 and have been as compared to nitrate distribution at the beginning of simulation (July 2007, Fig. 9).

This distribution of nitrate values can be explained by the fact that water quality in a given location depends not only on the agricultural and urban uses of the area directly overlying the location, but also from the quality of water inflowing from a greater distance. Lalehzari et al. (2009) shows the nitrate concentration is increased in the summer due to agricultural activities and consumption of nitrogen fertilizers. 


\section{Conclusion}

In this study, the effects of wastewater recharge and agricultural activities on the water quality and groundwater system are modeled using a finite difference groundwater model.

MT3D is suitable tool for studying influence of agricultural land use on nitrate leaching from soils towards deeper zones. Maximum nitrate concentration was observed in Bahram-Abad village. Because located in down wastewater treatment system of Shahrekord and near the village wastewater wells.

Nitrate concentration in the north plain is higher than average because of enhancement agricultural land-use and using azotic fertilizer.

It has also been shown that land use plays an important role on the water quality change. Therefore, integrated aquifer management strategies can only feasibly be designed when water quality analyses are complimented with land use and discharge volume.

Acknowledgments This study was supported by the Regional Water Company of Chaharmahal and Bakhtiari Province through the projects numbers 310/86/9414 and CHE-86002.

\section{References}

Andersen MS, Baron L, Gudbjerg J, Gregersen J, Chapellier D, Jakobsen R, Postma D (2007) Discharge of nitrate-containing groundwater into a coastal marine environment. J Hydrol 336:98-114

Anon (2000) Visual MODFLOW V.2.8.2 User's manual for professional applications in three-dimensional groundwater flow and contaminant transport modeling. Waterloo Hydrogeologic Inc, Ontario

Bazargan-Lari MR, Kerachian R, Mansoori A (2009) A conflictresolution model for the conjunctive use of surface and groundwater resources that considers water-quality issues: a case study. Environ Manage 43:470-482

Chiang WH, Kinzelbach W (2000) 3-D groundwater modeling with PMWIN. Springer-Verlag Berlin Heidelberg, New York, p 346

Conan C, Bouraoui F, Turpin N, Marsily G, Bidoglio G (2003) Modeling flow and nitrate fate at catchment scale in Brittany (France). J Environ Qual 32:2026-2032

Diersch HJG (2005) WASY software FEFLOW, finite element subsurface flow and transport simulation system, user's manual. Germany, Berlin

Don NC, Araki H, Yamanishi H, Koga K (2005) Simulation of groundwater flow and environmental effects resulting from pumping. Environ Geol 47:361-374

Ducci D (1999) GIS techniques for mapping groundwater contamination risk. Nat Hazards 20:279-294

Ehteshami M, Sharifi A (2007) Evaluating qualitative modling shahre ray aquifer. Tech sci Subsistence Envi 8(4):1-9

Faidi HA, Garcia LA, Albertson MM (2002) Development of a model for simulation of solute transport in a stream-aquifer system. Environ Model Assess 7:191-206

Fetouani S, Sbaa M, Vanclooster M, Bendra B (2008) Assessing ground water quality in the irrigated plain of Triffa. (North-east Morocco). Agric Water Manag 95(2):133-142
Gurunadha Rao VVS, Gupta SK (2000) Mass transport modeling to assess contamination of a water supply well in Sabarmati River bed aquifer, Ahmedabad City, India. Environ Geol 39(8):893900

Ishida S, Tsuchihara T, Yoshimoto S, Imaizumi M (2011) Sustainable use of groundwater with underground dams. Jpn Agric Res Quart 45(1):51-61

Lalehzari R (2008) The effect of wastewater recharge on nitrate distribution in Shahrekord aquifer using MT3D model. M.Sc. Thesis. Shahrekord University, Shahrekord, p 130

Lalehzari R, Tabatabaei SH, Yarali N (2009) Variation of monthly nitrate contamination of groundwater in Shahrekord aquifer and its mapping using GIS. Iran Water Res J 3(4):9-17

Lautz LK, Siegel DI (2006) Modeling surface and groundwater mixing in the hyporheic zone using Modflow and MT3D. Adv Water Resour 29(11):1618-1633

Leake SA, Prudic DE (1991) Documentation of a computer program to simulate aquifer-system compaction using the modular finitedifference groundwater flow model. Techniques of Water Resources Investigation, US Geological Survey, Reston

McDonald MG, Harbaugh AW (1988) Modflow, a modular threedimensional finite difference ground-water flow model, U. S. Geological Survey, Open-file report, USA, pp 83-875

Obeidat MM, Massadeh AM, Al-Ajlouni AM, Athamneh FS (2007) Analysis and evaluation of nitrate levels in groundwater at AlHashimiya area Jordan. Environ Monit Assess 135(1-3): 475-486

Pacheco J, Cabrera A (1997) Groundwater contamination by nitrates in the Yucatan Peninsula Mexico. Hydrogeol J 5(2):47-53

Papadopoulou MP, Karatzas GP, Bougioukou GG (2007) Numerical model ling of the environmental impact of landfill leachate leakage on groundwater quality-a field application. Environ Model Assess 12:43-54

Passarella G, Caputo MC (2006) A methodology for space-time classification of groundwater quality. Environ Monit Assess 115:95-117

Peeters L, Haerens B, Van der Sluys J, Dassargues A (2004) Modeling seasonal variations in nitrate and sulphate concentrations in a vulnerable alluvial aquifer. Environ Geol 46:951-961

Saeed MM, Bruen M (2004) Simulation of hydrosalinity behavior under skimming wells. Irrigat Drain Syst 18:167-200

Selle B, Minasny B, Bethune M, Thayalakumaran T, Chandra S (2011) Applicability of Richards' equation models to predict deep percolation under surface irrigation. Geoderma 160:569-578

Tabatabaei SH, Lalehzari R (2009) Determination of the contaminant sources by mapping tools in Shahrekord aquifer Iran. International Groundwater Symposium, Thailand

Tabatabaei SH, Lalehzari R, Nourmahnad N, Khazaei M (2010) Groundwater Quality and Land Use Change (A Case Study: Shahrekord Aquifer, Iran). J Res Agric Sci 6:39-48

Tariq SR, Shah MH, Shaheen N, Jaffar M, Khalique A (2007) Statistical source identification of metals in groundwater exposed to industrial contamination. Environ Monit Assess 138(1-3):159-165

Wang PP, Zheng C (2005) Contaminant transport models under random sources. Groundwater 43(3):423-433

Wang S, Sho J, Song X, Zhang Y, Huo Z, Zhou X (2008) Application of MODFLOW and geographic information system to groundwater flow simulation in North China Plain. China Environ Geol 55:1449-1462

Wingle WL, Poeter EP, McKenna SA (1999) UNCERT: geostatistics, uncertainty analysis and contaminant transport modeling. Comput Geosci 25:365-376

World Health Organization (2006) Guidelines for drinking-water quality. vol 1. World Health Organization, Geneva, p 515 
Wriedt G, Rode M (2006) Modeling Nitrate transport and turnover in a lowland catchment system. J Hydrol 328:157-176

Zheng C (1990) MT3D, A modular three-dimensional transport model for simulation of advection, dispersion and chemical reactions of contaminants in groundwater systems, Report to the U.S. Environmental Protection Agency, New York, p 170 